\title{
Çalışanların Liderlik, Mobbing ve İş Tutumu Arasındaki İlişkilerinin İncelenmesi: Nahçivan Öğretmenler Enstitüsü
} (Araştırma Makalesi)

Examining Employees' Relations Between Leadership, Mobbing and Job

Attitude: Nakhchivan Teachers Institute

Doi: 10.29023/alanyaakademik.817851

Mustafa TUNAY

Dr. Öğr. Üyesi, İstanbul Gelişim Üniversitesi, Mühendislik ve Mimarlık Fakültesi, Bilgisayar Mühendisliği, İstanbul, Türkiye.

mtunay@gelisim.edu.tr

Orcid No: 0000-0001-8843-621X

\section{Ruslan KAMILOV}

Psikolog Uzman, İsmayıllı Eğitim Müdürlüğ̈̈, İsmayıllı, Azerbaycan.

ru.kamilov87@gmail.com

Bu makaleye atıfta bulunmak için: Tunay, M., \& Kamilov, R. (2021). Çalı̧̧anların Liderlik, Mobbing ve İş Tutumu Arasındaki İlişkilerinin İncelenmesi: Nahçivan Öğretmenler Enstitüsü. Alanya Akademik Bakış, 5(1), Sayfa No.473-485.

\section{Anahtar kelimeler: \\ Liderlik, Mobbing, \\ Iş Tutumu, \\ Performans}

Makale Geliş Tarihi: 29.10.2020

Makale Kabul Tarihi: 02.01.2021

Keywords:

Leader, Mobbing,

Job Attitude,

Job Performance

\section{ÖZET}

Yapılan bu çalışmada liderlik, mobbing (yıldırma) ve iş tutumu gibi kavramlar üzerinde durularak ve geçmişten günümüze süregelen liderlik teorilerine, mobbing algllarına detayl olarak yer verilmiştir. Liderlik tarzlarından hangilerinin mobbing oluşumuna zemin hazırladığını, bunun çalışanların iş tutumu performansları üzerinde nasıl etkiler oluşturabileceği ve çalıştı̆̆ kurumlardaki çalışma süresinin liderlik tarzları ile mobbing algısının arasındaki ilişkiyi ölçerek, bunun iş tutumu üzerinde nasıl etki yaratabileceği gibi hususlar, yapılan bu çalışmada belirtilmiştir. Çalışmada araştırma birimi olarak, Nahçivan Özerk Cumhuriyeti!nde bulunan Nahçivan Öğretmenler Enstitüsü (NÖE) seçilmiştir. Nahçivan Öğretmenler Enstitüsü bünyesinde yer alan yöneticiler (rektör, rektör yardımcısı, dekan ve bölüm başkanı) ve çalışanları (öğretim görevlisi/üyesi) arasındaki iletişim şekli ve davranış tarzlarını belirlemek amacıyla SPPS 22 istatiksel analiz programından yararlanılmıştır. Çalışanların demografik özelliklerinin yanı sıra, çalıştıkları birimlerinden de bilgi edinerek liderlik tarzlarının ve mobbing algısının; çalışanların iş tutumu, iş performansı üzerine etkilerinin önemi vurgulanmıştır. Araştırmanın sonucunda, çalışanların mobbing davranışı ve liderlik özellikleri ile iş tutumu arasında anlamlı bir ilişki olduğu görülmüş̧ür.

\section{ABSTRACT}

In this study, concepts of leadership, mobbing and job attitude are emphasized, and leadership theories and mobbing perceptions are given in 
detail from past to present. Issues such as leadership styles create the basis for mobbing, how this may have an impact on the performance of employees' work attitude, and how this can have an impact on job attitude by measuring the relationship between leadership styles and mobbing perception in the institutions. In the study, research unit was chosen Nakhchivan Teachers Institute (NTI), located in Nakhchivan Autonomous Republic. SPPS 22 statistical analysis program was used in order to determine the communication style and behaviors between administrators (rector, vicerector, dean and head of department) and employees (lecturers) at Nakhchivan Teachers Institute. In addition to the demographic characteristics of the employees, the importance of leadership styles and the effects of mobbing perception on employees' job attitude and job performance was emphasized by obtaining information. As a result of the study, it was observed that there was a significant relationship between the behavior of mobbing and characteristics of leadership for employees and their job attitude.

\section{GİRIŞ}

İnsanları etkileyebilme gücüne sahip olan liderlik, işletmeler için çok önemli bir araçtır. Liderlik, insanlara yön göstermekle onları motive ederek işlerini daha iyi yapabilmeleri ve işletmenin hedeflerine ulaşmasını kolaylaştıracak ortamlar yaratabilme yeteneğidir (Kesken ve Ayyıldız, 2008: 729-754; Uğurluoğlu ve Çelik, 2009: 121-156). Yetenek de lider kişinin yaşam tarzı ve geçmişte edinmiş olduğu tecrübeleri kapsamında oluşur. Lider; etki eden, yöneten, güzel örnekler verebilen, topluma yararlı olanı göstererek doğru değerlendiren, sorumlulukla, akılla davranan insandır (Kılıç vd., 2011: 5-22). Lider, başkalarından aldığ 1 bilgi ve deneyimlerle daha çok bilgi edineceğini ancak kendi aklı ile vereceği karar doğrultusunda daha sağlam adımlar atmanın önemini bilmektedir (Erdem ve Dikici, 2009: 198-213). Bu nedenle çevreye danışır ama son kararı tüm sorumluluğu üstlenerek kendisi karar verir. İnsanların uzun süre hayatlarını geçirdikleri iş ortamları stresten, fiziki ve psikolojik baskılardan uzak ise çalışanlar verimli çalışmakla beraber aynı zamanda örgüte bağlılığını da artırmaya çalışır (Mehmet vd., 2004: 423-446; Önen ve Kanayran, 2015: 4364).

Mobbing algısı; bu düzeni bozabilen, örgüt içindeki çalışanların çalışma ortamını, aynı zamanda barış ortamının bozulmasını etkilemekle beraber çalışanların daim stresle karşı karşıya kalmasını da gösteren büyük bir sorun olarak karşımıza çıkmaktadır (Duffy ve Sperry, 2007: 398-404). Mobbing algısı, bazen bir bazen birden fazla kişinin bir kişiyi hedef alarak psikolojik ve fiziki zararlara yol açan sık ve uzun dönemli (bazen yıllarca süre bilir), organize edilmiş ve sürekli tekrarlanan tacizci davranışlarına-saldırganlıklarına- denir (Leymann, 1996: 165-184; Vandekerckhove ve Commers, 2003: 41-50). Dünyada çok hızlı bir şekilde artan mobbing probleminin istatistik araştırmalarına bakacak olursak İsveç’te bir grup bilim adamının yaptığı araştırmada 4.4 milyon iş gücüne sahip \%3.5'i yani 154,000 insan iş yaşantısında mobbinge maruz kalmıştır (Leymann, 1990: 119-126). Bu bağlamda bir yıldaki intihar oranlarının \%10 ile \%20 kısmının iş yaşantısındaki mobbing sonucu oluştuğu tahmin ediliyor (Leymann ve Gustafsson, 1996: 251-275). İş yerlerinde mobbingin iş görene ve iş yerine ekonomik açıdan verdiği zarar çok fazladır. Örneğin; Almanya'da mobbing, 1,000 çalışanı olan bir işletmeye yarattığı zarar yaklaşık olarak 112,000\$; bunun yanında dolaylı maliyeti ise yaklaşık 56,000\$ olarak hesaplanmıştır (Tınaz, 2006: 11-22). 
Performans, çalışanların iş tutumunu belirleyen önemli bir unsurdur. İki kavram arasındaki ilişkiyi, çalışanın kendisine verilmiş görevi belirli bir zaman kapsamında yerine getirmek için yapmış olduğu çalışmaların sonucuna ulaşma bütünü olarak da ifade edilmektedir (Çekmecelioğlu ve Dinçel, 2013: 125-139). Personelin işte göstermiş olduğu performans, onun iş tutumunun belirlenmesine ve örgütün hedeflerine ulaşabilmesi için temel olgudur (Gürbüz vd., 2010: 69-76). Bu yüzden her örgütün bulunduğu yerde veya sektörde rekabet edebilmeleri, hedeflerine kısa sürede varabilmeleri açısından yüksek performans gösteren çalışanlara ihtiyaç duyulmaktadır (Zehir ve Erdoğan, 2011: 1389-1404).

Bu çalışmada liderlik, mobbing ve iş tutumu kavramları üzerinde daha çok durulacak ve geçmişten günümüze akıp gelen liderlik teorilerine, mobbing algısına detaylı olarak bakılacaktır. Çalışmanın amacı çalışanın çalıştığı kurumdaki çalışma süresinin liderlik tarzları ile mobbing algısının arasındaki ilişkiyi ölçmek, liderlik tarzlarının ve mobbing algısının iş tutumu üzerinde nasıl etki yarattığını anket uygulamasıyla belirlemektir. Liderlik tarzlarından hangilerinin mobbing oluşumuna zemin hazırladığını, bunun çalışanların iş tutumu performansları üzerinde nasıl etkiler oluşturabileceği ve çalıştığı kurumlardaki çalışma süresinin liderlik tarzları ile mobbing algısının arasındaki ilişkiyi ölçerek, bunun iş tutumu üzerinde nasıl etki yaratabileceği gibi hususlar, yapılan anket çalışmasıyla belirlenmiştir.

\section{LITERATÜR TARAMASI}

\subsection{Liderlik}

Lider sözcüğünün sözlük anlamına bakacak olursak güç, otorite, emir vermek, ödüllendirmek, yol göstermek, aydınlatmak, ileriyi gösterebilen, öğretebilen, birlikte çalıştığı kişilerin ihtiyaclarını ve isteklerini zamanında fark ederek gereken yardımı, önlemi yapabilen yaratıcı kimsedir (Saruhan vd., 2009). Günümüzde liderliğin tanımlarının birçoğuna bakıldığında aşağıdaki belirtilen dört değişken gösterilmektedir (Mc Gregor, 1944: 55; Bennis vd., 1966).

1. Lider şahsın bireysel olan özellikleri ve tanımlamarı,

2. Astların davranış gereksinimeleri ve diğer kendine has özellik tanımlamaları,

3. Örgütün amaçlarının yapısı ve uygulanacak görev niteliklerinin tanımlanması,

4. Sosyal ekonomik durum ve siyasi ortam.

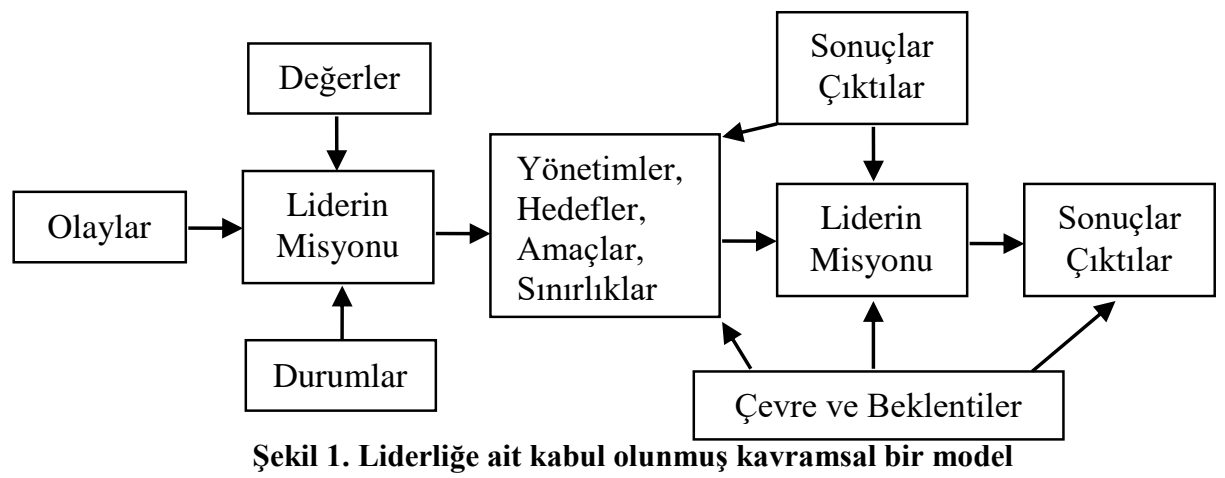

Immegart’ta (1988), liderliğin anlamlarının güçlüğünü belirterek liderliğe ilişkin kabul edilmiş Şekil 1'de görüldüğü üzere bir model geliştirmiştir. Farklı bir perspektiften bakıldığında liderlik tarzları ile ilgili literatür taraması yaptığımız zaman birçok araştırmacı 
tarafından çalışmalarına konu edildiğini, aynı zamanda liderin sergilemekte olduğu davranış tarzlarıyla ilgili birçok sınıflamalar yapıldığını görmüş oluyoruz (Önder ve Taş, 2010: 17-30) Liderin liderlik vazifelerini yerine getirirken farklı davranışlarda bulunması işletmenin faaliyet alanı, yapısal ve çevresel değişkenlerin yaratmış olduğu etkilerle oluyor. Liderlik tarzlarına bakacak olursak iki temel grupta toparlandığı görülmektedir.

\subsection{Mobbing Kavramı}

Psikolojik taciz, kökü "mob" olan İngilizce sözünden gelmektedir. "Mob" kelimesi şiddetli, şiddetsiz kalabalık anlamına gelmektedir. Sözcük Latince "mobil vulgus"tan türetilmiştir. Öte yandan mobil vulgus; dengesiz kalabalık, şiddete yönelik bir toplum gibi anlamlara sahiptir. Mobbing; bir yerde toplanma, çevreyi kuşatma, toplu saldırı veya rahatsız etme anlamına gelir (Çobanoğlu, 2005). Mobbing kavramına yakın bir diğer kavram da "zorbalığa" uğramadır. Zorbalık, bir kişinin veya bir grubun, bir kişiye veya zayıf ve sürekli olarak bir gruba karşı daha güçlü bir psikolojik veya fiziksel baskıya atıfta bulunmasıdır (Lewis D., 1996: 65-81). Mobbing, literatür de yeni bulunan bir kavram olduğundan dolayı Türkçede karşılığının net bir açılımı bulunmamakla birlikte terminoloji sorunu yaşanmaktadır. Mobbing kavramıyla ilgili yapılan araştırmalarda yukarıda belirtilen birçok tanımlarda ortak üç faktör bulunmaktadır. İlk olarak mobbing yapan kişinin (saldırgan) isteğine bakmaksızın yapmış olduğu eylemin, mağdur kişi üzerinde bıraktığı etkilerdir. İkincisi bu etkilerin negatif yanı mağdur kişiye hasar verip vermediğidir. Üçüncü unsur ise saldırganın mobbing eylemi konusundaki ısrarlı davranışıdır. Başka bir deyişle mobbingin ne sıklıkla ve ne kadar sürede devam ettirildiğidir (Žukauskas ve Vveinhardt, 2009: 103-113).

Farklı bir noktadan bakıldığında, çalışanların iş tutumunu etkileyen bir faktör olan mobing türlerinden biri psikolojik zorbalık (yıldırma) kavramı, işyerinde iş arkadaşları veya işveren şahıslar tarafından defalarca saldırıya uğrayan psikolojik bir terörizm biçimidir (Dündar ve Acar, 2008: 111-120). Çalışan kişilere üstleri tarafından, astları veya eşit diğer çalışan şahıslar tarafından planlı olarak uygulanan her türlü taciz, şiddet, tehdit ve aşağılamayı ifade eden bir süreçtir (Karavardar, 2009; Karcioğlu ve Çelik, 2012). Kişinin çalışma arkadaşları tarafından sistematik olarak uzun süreli duygusal ve ruhsal açıdan yıpratılması ve hatta işten ayrılmaya zorlanması anlamına gelen bir kavram olarak da ifade edilebilir. Bu doğrultuda hedeflenen şahıs, karşı koyabilir; çevreden uzaklaşabilir ya da duruma aynı şekilde cevap verirse psikolojik zorbalığı sonlandırabilir. Bu durum karşısında direnemezse veya zorluluk çekerse zihinsel açıdan, ruhsal açıdan ve bedensel açıdan tükenir ve işine odaklanma da zorluluk çekebilir. (Tınaz, 2006; Çobanoğlu, 2005).

İş yerinde mobbingin oluşmasının sebepleri üzerinede yapılmış olan çeşitli araştırmalar mobbingin nedenlerini üçe ayırmaktadır (Altuntaş, 2010: 2995-3015; Şimşek, 2013: 36-45). Bu nedenleri şöyle sıralanmaktadır:

1. Saldırgan kişinin psikolojik yapı şeklinden oluşan nedenler,

2. Duygusal saldırıya uğramış insanın (mağdurun) psikolojik halinden kaynaklanan nedenler,

3. Organizasyonun yapı şeklinden kaynaklanan nedenlerdir.

Leymann (1996), psikolojik zorbalığa, liderlik meselelerine ve çalışma ortamından kaynaklanan önemli sorunlara değinmektedir. Bunun yanında, şekil 2'de görüldüğü üzere mobbing eylemlerine neden olan faktörler ifade edilmektedir. Görüldüğü üzere kişişel nedenler ve örgütsel nedenler olarak ikiye ayrılmaktadır. Kişisel nedenlerde saldırganın ve 476 
mağdurun kişiliği ve örgütsel yapısı; örgütsel nedenlerde ise kötü yönetim, kurumsallaşmamış kurumlar, stress, liderin duygusal zekadan yoksunluğu ve monotonluğu olarak ifade edilmektedir. Farklı bir perspektiften bakıldığında, psikolojik zorbalığın olası nedeni üzerine bir başka bakış açısı "sosyal dışlanma sürecine" ve "sosyal sisteme" bağlı olmasıdır (Cilga, 2009: 7-26; Yaman, 2009).
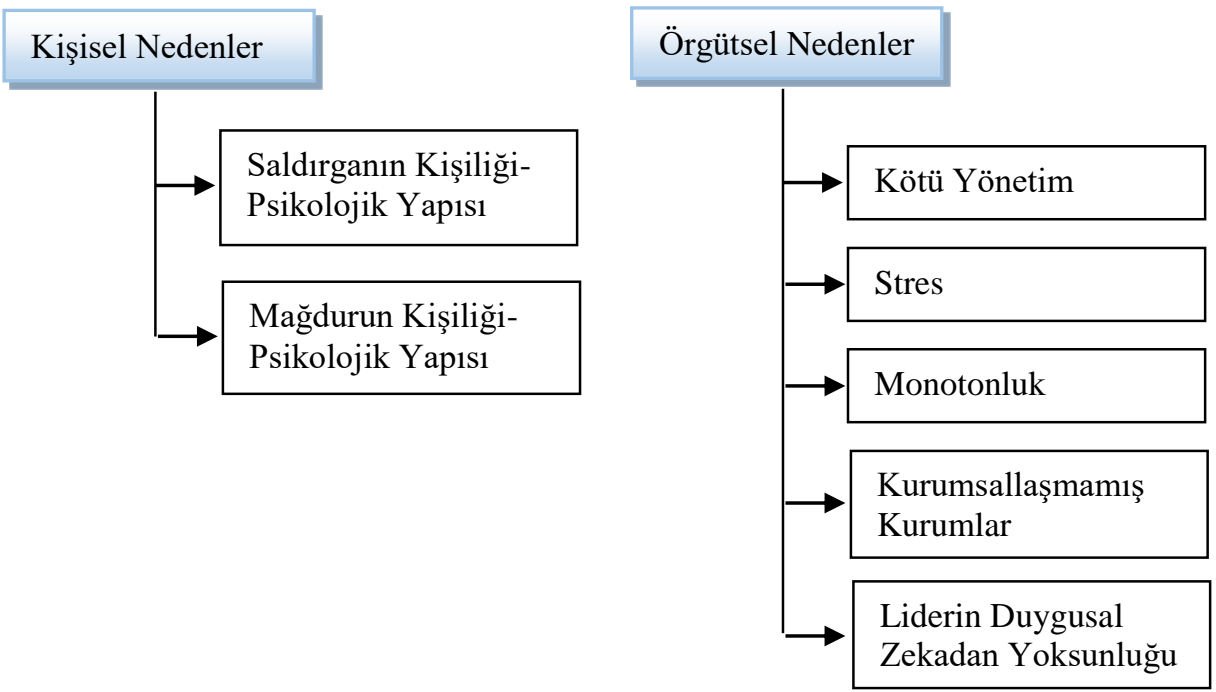

Şekil 2. Mobbing eylemlerine neden olan faktörler

\section{3. Çalışanın İş Tutumları ve Performansı}

Örgütsel davranış kapsamında önemli yeri olan örgüt bağlılığı, iş tatmini aynı zamanda işten ayrılma niyeti gibi iş tutumları, çalışanların işe yönelik performanslarını etkilemektedir. Bu bağlamda bu unsurlar örgütün etkinliğinin en önemli faktörleri olarak karşımıza çıkmaktadır (Çekmecelioğlu ve Günsel, 2011: 33-43). Çalışanın iş performansı; işe devamlılığı, işten ayrılması örgüte bağlılık ve iş tatmini açısından oldukça kritik tutumlardır. Bir işletmede örgütün performans yapısı, iş tutumu, çalışma şartları, amacı, organizasyon misyon türüne ve organizasyonda inancına bağlıdır (Gökçek, 2006). İş performansı ile iş tutumu arasında önemli bir etkileşim vardır. İşletmeler organizasyonel hedeflerine ulaşmak ve faaliyet gösterdikleri sektörde rekabet avantajı elde etmek için yüksek performanslı çalışanlara ihtiyaçları vardır (Cevrioğlu, 2007). Bu doğrultuda, uygulanan kurallar ve prosedürler, tatmin edici çalışma tarzını sağlar ve çalışanların iş tutumunu belirler. Çalışanların işlerini yürütebilmeleri için yerine getirdikleri uzmanlıklar ve iş rolleri, iş performansında bireysel değişim için önemli bir kaynak olarak düşünülebilir (Janssen ve Van Yperen, 2004: 368-384; Tarlığ, 2006). Bir işletmenin performansı, bireyin iş tanımının gereklerini yerine getirme yeteneğine dayanmaktadır. Bu bakış açısı, "tanımlanmış bir meslek", bireyin mesleğinin tanımıyla bağlantılı davranışlar ve kurumun amacı ile ilişkili olarak değerlendirilmektedir. İşlerin ve kurumların değişen içeriği de bireysel iş performansı algısını değiştirmektedir. Sistemler birbirine bağlı olduğundan ve limitleri belirsiz olduğundan eski yaklaşımlar iş performansının tanımlanmasında önemini yitirmektedir (Gürbüz vd., 2010; Çekmecelioğlu ve Dinçel, 2013). 


\section{YÖNTEM}

Araştırmanın evrenini, Nahçivan Özerk Cumhuriyeti’nde bulunan Nahçivan Öğretmenler Enstitüsünde görev alan yönetici ve öğretim görevlisi olmak üzere toplam 250 kişiden oluşmaktadır. Araştırma birimi olarak Nahçivan Öğretmenler Enstitüsü seçilmiştir. Yapılan çalışmada çalışanların demografik özelliklerinin yanı sıra çalıştıkları birimlerinden de bilgi edinerek, liderlik tarzlarının ve mobbing algısının iş görenlerin iş tutumu ve performansı üzerindeki etkilerinin belirlenmesi hedeflenmiştir. Nahçivan Özerk Cumhuriyeti'nde bulunan Nahçivan Öğretmenler Enstitüsünde 250 toplam çalışanı arasından \%90 güvenirlilik düzeyi, \%6.2 yanılma payı göz önünde bulundurulduğunda gerekli örneklem 131 çalışan olarak belirlenmiştir. Örnekleme büyüklüğünün minimumu hesaplanması için, aşağıdaki formülden yararlanılmıştır.

$$
\begin{aligned}
& \mathrm{x}=\mathrm{Z}(\mathrm{C} / 100)^{2} \mathrm{r}(100-\mathrm{r}) \\
& \mathrm{n}={ }^{\mathrm{N} x} l_{\left((\mathrm{N}-1) \mathrm{E}^{2}+\mathrm{x}\right)} \\
& \left.\mathrm{E}=\mathrm{Sqrt}^{(\mathrm{N}-\mathrm{n}) \mathrm{x}} 1_{\mathrm{n}}(\mathrm{N}-1)\right]
\end{aligned}
$$

Toplanan örneklem ise $131^{\prime}$ 'dir. Örneklemin cinsiyet ve yaş açısından homojenliğini sağlamaya çalışmışlardır.

Araştırmada anket uygulaması, verilerin toplanması aracı olarak yararlanılmıştır. Dört bölümden oluşan anket formu önceden yapılmış literatürden yararlanılmış ve toplamda 92 adet soruluk bir anket formu ile derlenip, hazırlanmıştır. Anketin birinci kısmında çalışanların demografik özelliklerini belirlenmesi için 8 adet soru; ikinci bölümde çalışanların nasıl mobbing davranışlarına yakalandıklarını belirtmek amaçlı 45 soru; üçüncü bölümde iş tutumunu belirlemek amaçlı 4 adet soru; son bölümde ise araştırmaya katılanların liderlik tarzlarına ilişkin 35 adet soru yer almaktadır. Araştırma soruları, 5'li Likert ölçeğinde düzenlenmiştir. Likert Sistemi 'Kesinlikle katılmıyorum', 'Katılmıyorum', 'Fikirim yok', 'Katılıyorum', 'Kesinlikle katılıyorum' şeklinde beşli cevap tekniği içeren bir sistemdir. Araştırmanın verileri, Statistical Package for Social Science (SPSS) 22 yazılımı ile analiz edilmiştir. Anketler, 15-20 Nisan 2017 tarihinde etik kurallar çerçevesinde uygulanmıştır. Ölçeğin güvenirliliğiyle ilgili çalışmalarında Cronbach Alpha katsayısı hesaplanmıştır. Cronbach Alpha iç tutarlılık katsayıları Mobbing alt ölçeği için .972; liderlik alt ölçeği için .877; Tutum alt ölçeği için .822 olarak belirlenmiştir. Güvenirlik katsayılarının .70 ve daha yüksek olması ölçeklerin güvenirliği açısından yeterli derecede olduğu belirtilmektedir (Santos, 1999: 1-5).

\section{ARAŞTIRMANIN BULGULARI}

Çalışmanın bu bölümünde anket sorularından elde edilen verilerin en önemli kısımları, tablo ve şekiller halinde bulgularda belirtilmiş ve yorumlanmıştır. Çalışmada, yöneticiler (rektör, rektör yardımcısı, dekan ve bölüm başkanları) ve çalışanları (öğretim elemanı/üyesi) arasındaki iletişim şekli ve davranış tarzlarını belirlemek amacıyla Nahçivan Öğretmenler Enstitüsünün (NÖE) 250 kişiden oluşan çalışanlarında 131 geri bildirim olarak gelen anket formundan alınmış sonuçlara göre incelenmiştir.

\section{1. Çalışanlarının Demografik Özellikleri}

Nahçivan Öğretmenler Enstitüsünün (NÖE) anket sorularına cevap veren kişilerin cinsiyet dağılımlarına göre, anket sorularına cevap veren \%74 ile bayan (97), \%26 ile erkek (34) 
katılımı sağlanmıştır. Nahçivan Öğretmenler Enstitüsünün (NÖE) anket sorularına cevap veren kişilerin yaş dağılımlarına göre ise, anket sorularına cevap veren \%26 ile 18-26 (34) yaş aralığı; \%11.50 ile 27-32 (15) yaş aralığı; \%23.70 ile 33-40 (31) yaş aralığı; \%38.90 ile 41üzeri (51) yaş aralığında kişilerin katılımı sağladığı görülmektedir. Nahçivan Öğretmenler Enstitüsünün (NÖE) anket sorularına cevap veren kişilerin eğitim durumlarını incelendiğinde, anket sorularına cevap veren \%6.10 ile Ön Lisans (8); \%30.50 ile Lisans (40); \%33.60 ile Yüksek Lisans (44); \%29.80 ile Doktora (39) eğitimlerini tamamlamış katılımcıların olduğu görülmektedir. Nahçivan Öğretmenler Enstitüsünün (NÖE) anket sorularına cevap veren kişilerin NÖE'deki çalışma sürelerini incelendiğinde, anket sorularına cevap veren \%23.70 ile 0-2 (31) yıl aralığında, \%33.60 ile 3-7 (44) yıl aralığında; \%11.50 ile 8-12 (15) yıl aralığında, \%31.30 ile 13-üzeri (41) yıl aralığında çalışma sürelerine sahip oldukları görülmektedir.

\subsection{Hipoteze Dayalı Bulgular ve Yorumlar}

Mevcut araştırmada ölçme aracı olarak Rensis Likert'in (1932) “dereceleme toplamlarıyla ölçekleme" modelini kullanarak ölçek oluşturulmuştur. Ölçeğin güvenirliliğiyle ilgili çalışmalarında Cronbach Alpha katsayısı hesaplanmış ve tablo 1'de gösterilmiştir.

Tablo 1. Güvenirlik Testi

\begin{tabular}{|l|l|}
\hline Güvenirlilik İstatistikleri & Cronbach's Alpha \\
\hline Mobbing & .972 \\
\hline Liderlik & .877 \\
\hline Tutum & .822 \\
\hline
\end{tabular}

Korelasyon analizi iki değişken arasında gerçekleşen doğrusal ilişkiyi, bir değişkenin iki değişken ile olan ilişkisini ya da ikiden fazla çok değişken ile olan ilişkisini, test etmek ise bu ilişkinin derecesini ölçmek için kullanılan istatiksel bir yöntemdir (Filiz ve Kolukısaoğlu, 2012: 59-74). Böylelikle yapılan test değişkenler arası ilişkinin ifade edilmesine yardım ederek benzer sonuçları önceden tahmin edecektir. SPSS programında Korelasyon analizi sonuçlarından elde edilen bilgiler doğrultusunda veriler arasında hiçbir ilişki olmadığı Tablo 2' de ki anlamlılık değerlerine bakıldığında görülmektedir.

Tablo 2. Korelasyon Analizi

\begin{tabular}{|l|l|c|c|c|}
\hline \multicolumn{2}{|c|}{ Kolerasyon } \\
\hline \multirow{3}{*}{ Mobbing } & Mobbing & Tutum & Liderlik \\
\hline \multirow{3}{*}{ Tutum } & Pearson Korelasyon & 1 & .119 & -.015 \\
\cline { 2 - 5 } & Sig. (2-tailed) & & .176 & .868 \\
\cline { 2 - 5 } & $\mathrm{N}$ & 131 & 131 & 131 \\
\hline \multirow{3}{*}{ Liderlik } & Pearson Korelasyon & .119 & 1 & .018 \\
\cline { 2 - 5 } & Sig. (2-tailed) & .176 & & .836 \\
\cline { 2 - 5 } & $\mathrm{N}$ & 131 & 131 & 131 \\
\cline { 2 - 5 } & Pearson Korelasyon & -.015 & .018 & 1 \\
\cline { 2 - 5 } & Sig. (2-tailed) & .868 & .836 & 131 \\
\cline { 2 - 5 } & $\mathrm{N}$ & 131 & 131 & \\
\hline
\end{tabular}

Verilerin normal dağılıma uygunluğunu belirlemek amacıyla çeşitli normallik testlerinden yararlanmak mümkündür. Bu tür testler içerisinde en bilinenleri Ki-Kare, KolmogorowSmirnov, Lilliefors ve Shapiro - Wilk normallik testleridir. Shapiro Wilk kısmına ve orada da 
Sig. kısmına göre eğer değişkenin Sig. değeri 0.05 'ten büyükse normal dağıldığı kabul edilir, 0.05 'ten küçükse normal dağılım göstermediği kabul edilir. Tablo 3' te görüldüğü üzere Sig. 0.05 ten küçük olduğu için normal dağılmadığı görülmektedir.

Tablo 3. Liderlik tarzlarının dağılımının test sonuçları

\begin{tabular}{|c|c|c|c|c|c|c|c|c|}
\hline \multicolumn{9}{|c|}{ Tests of Normality } \\
\hline & \multicolumn{4}{|c|}{ Kolmogorov-Smirnov $^{\mathrm{a}}$} & \multicolumn{4}{|c|}{ Shapiro-Wilk } \\
\hline & Statistic & D & & Sig. & Statistic & & & \\
\hline Liderlik & & .106 & 131 & .001 & & .972 & 131 & .004 \\
\hline
\end{tabular}

Liderlik ölçeği için hipotezler oluşturulmuştur: H0. Verilerin dağılımı normale uyar. H1. verilerin dağılımı normale uymaz. Tablo 3 'de görüldüğü üzere, $\% 5$ anlamlılık seviyesinde her iki test için liderlik verilerinin sig. (anlamlılık) değeri 0.001 ve 0.004 'dir. Her iki değer de 0.05 'ten küçük olduğu için H0 hipotezi kabul edilmez. Dolayısıyla, verilerin normal dağılıma uymadığı söylenebilir.

Tablo 4. İs tutumu dağılımının test sonuçları

\begin{tabular}{|c|c|c|c|c|c|c|c|c|}
\hline \multicolumn{9}{|c|}{$\begin{array}{r}\text { Tests of Normality } \\
\end{array}$} \\
\hline & \multicolumn{4}{|c|}{ Kolmogorov-Smirnov $^{\mathrm{a}}$} & \multicolumn{4}{|c|}{ Shapiro-Wilk } \\
\hline & Statistic & $\mathrm{Df}$ & & Sig. & Statistic & & & \\
\hline İş Tutum & & .235 & 131 & .000 & & .773 & 131 & .000 \\
\hline
\end{tabular}

Tutum ölçeği için şu hipotezler oluşturulmuştur: H0 = Verilerin dağılımı normale uyar. H1 = Verilerin dağılımı normal dağılıma uymaz. Tablo 4'de görüldüğü üzere, \%5 anlamlılık seviyesinde her iki test için tutum verilerinin sig. (anlamlılık) değeri 0.000 ve 0.000 'dir. Her iki değer de 0.05 'ten küçük olduğu için H0 hipotezi kabul edilmez. Yani verilerin normal dağılıma uymadı̆̆ı söylenebilir.

Tablo 5. Mobbing dağılımının test sonuçları

\begin{tabular}{|c|c|c|c|c|c|c|c|}
\hline \multicolumn{8}{|c|}{ Tests of Normality } \\
\hline & \multicolumn{4}{|c|}{ Kolmogorov-Smirnov $^{\mathrm{a}}$} & \multicolumn{3}{|c|}{ Shapiro-Wilk } \\
\hline & Statistic & Di & & Sig. & Statistic & Df & \\
\hline Mobbing & & & 131 & .000 & .530 & 131 & .000 \\
\hline
\end{tabular}

Mobbing ölçeği için şu hipotezler oluşturulmuştur: H0 = Verilerin dağılımı normale uyar. H1 $=$ Verilerin dağılımı normal dağılıma uymaz. Tablo 5'de görüldüğü üzere, $\% 5$ anlamlılık seviyesinde her iki test için Mobbing verilerinin sig. (anlamlılık) değeri 0.000 ve 0.000 'dir. Her iki değer de 0.05 'ten küçük olduğu için H0 hipotezi kabul edilmez. Yani verilerin normal dağılıma uymadığı söylenebilir.

Farklı bir perspektiften ele alındığında veriler normal dağılmadığı için ANOVA'nın parametrik olmayan test karşılığı olan Kuruskal-Wallias testi kullanılmıştır. Kuruskal-Wallias testi sayesinde veriler arasında anlamlı bağlantı olup olmadığı incelenmiştir. Yapılan, tablo karşılaştırmasını sonucunda, "ortalamaların kendi aralarında anlamlı fark yoktur" ifade etme olasılı̆̆ı Asymptotic Significance (Asym. Sig) ile belirtmektedir. Bu değer, 0.05'e eşit ya da daha küçükse, karşılaştırılan ortalamalardan en az ikisi arasında, istatistiksel açıdan önemli (manidar) yani anlamlı bir farklılık vardır kararı verilebilir. Eğer ki bu değer 0.05 'ten çok büyükse, bu grupların ortalamaları arasında hiçbir anlamlı farklılık yoktur, bu gruplar birbirine eşittir kararı verilebilir. Fakat unutulmamalı ki bu karar $\% 5$ yani 0.05 düzeyinde alınmış olan bir karardır. 
Tablo 6. Çalışanların aynı kurumda çalışma süreleriyle liderlik algıları arasındaki bağlantıyı ölçen Ki-kare testi

\begin{tabular}{|l|c|}
\hline \multicolumn{2}{|c|}{ Test Statistics a,b $^{\mathbf{a}, \mathbf{b}}$} \\
\hline Chi-Square & $\begin{array}{c}\text { Şu an çalışmakta olduğunuz kurumda kaç yıldır } \\
\text { çalışmaktasınız? }\end{array}$ \\
\hline Df & 7.213 \\
\hline Asymp. Sig. & 2 \\
\hline a. Kruskal Wallis Test & .027 \\
\hline b. Grouping Variable: liderlik & \\
\hline
\end{tabular}

Tablo 6'da belirtildiği üzere, çalışanların aynı kurumda çalışma süreleriyle liderlik algıları arasında anlamlı farklılık vardır hipotezi, gerçekleştirilen Kuruskal-Wallis Test sonucunun p < 0.05 olduğu için H1 hipotezi çalışanların aynı kurumda çalışma süreleriyle liderlik algıları arasında anlamlı farklılık vardır sonucuna varılmıştır.

Tablo 7. Çalışanların aynı kurumda çalışma süreleriyle mobbing algıları arasındaki bağlantıyı ölçen Ki-kare testi

\begin{tabular}{|l|c|}
\hline \multicolumn{2}{|c|}{ Test Statistics $^{\mathbf{a}, \mathbf{b}}$} \\
\hline Chi-Square & $\begin{array}{c}\text { Şu an çalı̧̧makta olduğunuz kurumda kaç yıldır } \\
\text { çalışmaktasınız? }\end{array}$ \\
\hline Df & 1.039 \\
\hline Asymp. Sig. & .308 \\
\hline a. Kruskal Wallis Test & \\
\hline b. Grouping Variable: mobbing & \\
\hline
\end{tabular}

Hipotez 2 olarak oluşturulan, H0 - çalışanların aynı kurumda çalışma süreleriyle mobbing algıları arasında anlamlı farklılık yoktur ve H1 - çalışanların aynı kurumda çalışma süreleriyle mobbing algıları arasında anlamlı farklılık vardır hipotezleri çerçevesinde gerçekleştirilen Kuruskal-Wallis Test sonucunun $\mathrm{p}>0.05$ olduğu için H0 hipotezi yani çalışanların aynı kurumda çalışma süreleriyle mobbing algıları arasında anlamlı farklılık yoktur sonucuna varılmıştır.

Tablo 8. Mobbing algısıyla çalışanların iş tutumu arasındaki farklılığı denetleyen Ki-Kare test sonucu

\begin{tabular}{|l|c|c|}
\hline & Mobbing & Tutum \\
\hline Chi-Square & $1938.314^{\mathrm{a}}$ & $138.717^{\mathrm{b}}$ \\
\hline Df & 18 & 10 \\
\hline Asymp. Sig. & .000 & .000 \\
\hline
\end{tabular}

Tablo 8'de belirtildiği üzere, çalışanların mobbing algısıyla iş tutumları arasında anlamlı bir ilişki vardır, hipotezi, gerçekleştirilen Mobbing algısıyla çalışanların iş tutumu arasında 
farklılığın olup olmadığı Pearson Ki-Kare testi ile incelenmiştir. Bu test sonucunda ikisi arasında $(\mathrm{P}<0.05)$ anlamlı bir farklılık olduğu bulunmuştur.

Tablo 9'da görüldüğü üzere oluşturulan, H0 - çalışanların liderlik algısıyla iş tutumları arasında anlamlı bir ilişsi yoktur ve H1 - çalışanların liderlik algısıyla iş tutumları arasında anlamlı bir ilişki vardır hipotezi çerçevesinde liderlik tarzlarıyla çalışanların iş tutumu arasında farklılık olup olmadığı Pearson Ki-Kare testi ile incelenmiştir. Bu test sonucunda ikisi arasında $(\mathrm{P}<0.05)$ anlamlı bir farklılık olduğu belirlenmiştir.

Tablo 9. Liderlik tarzlarıyla çalışanların iş tutumu arasındaki farklıı̆̆̆ denetleyen Ki-Kare test sonucu

\begin{tabular}{|l|c|c|}
\hline & Tutum & Liderlik \\
\hline Chi-Square & $138.717^{\mathrm{a}}$ & $69.601^{\mathrm{b}}$ \\
\hline Df & 10 & 29 \\
\hline Asymp. Sig. & .000 & .000 \\
\hline
\end{tabular}

\section{SONUÇ VE TARTIŞMA}

$\mathrm{Bu}$ araştırma, Nahçivan Özerk Cumhuriyeti'nde bulunan Nahçivan Öğretmenler Enstitüsündeki personellerinin çalıştıkları kurumdaki çalışma süreleriyle ilgili olarak liderlik, mobbing algısı arasındaki anlamlı bir bağlılık olup olmadığını ve liderlik tarzları ile mobbing algısının iş tutumu üzerindeki etkisini ölçen anket çalışması şeklinde yapılmıştır. İlk olarak anketi oluşturan soruların frekans tabloları çıkartılmış ve gerçeklik analizi ile ölçülen liderlik, mobbing algısı ve iş tutumu istatiksel olarak içsel tutarlılığı analiz edilip incelenmiştir. Analiz sonucuna göre: enstitüde çalışanlarının çoğunluğunu teşkil eden kadınlar (\%74.0) olduğu ve çalışanların çalıştıkları kurumda çalışma süreleriyle liderlik tarzları arasında anlamlı bir farklılık olduğu sonucuna varılmıştır. Araştırmanın analiz sonuçlarına göre çalışanların aynı kurumda çalışma süreleriyle mobbing algıları arasında anlamlı farklılığın olmadığı sonucuna varılmıştır. Buna karşın çalışanların mobbing ve liderlik değişkenleri ile iş tutumu arasında anlamlı bir farklılığın olduğu sonucuna varılmıştır.

Önceden yapılan literatürler incelendiğinde çalışanların iş tutumu düzeyleri kalite açısından iyileştirilmek isteniliyorsa öncelikle çalışanların liderlerine bakış açıları değiştirilmelidir. Ayrıca çalışanların çalışma sürelerinin mobbing algısıyla anlamlı bir ilişkisi olmadığı, bir kurumda ister kısa ister uzun süre çalışan olsun her bir çalışan psikolojik tacize maruz kalabilir sonucuna varılmıştır. Kötü liderlik tarzlarının mobbingin oluşmasının, çalışanın iş tutumunu kötü yönde etkilediğini ortaya çıkarmış ve psikolojik tacizin işletme üzerinde negatif etkilerinin olduğu ifade edilmiştir. Çalışanların mobbing ile ilgili karşılaştığı davranışlar incelendiğinde; konuşmalarının kesilerek söylediklerinin dikkate alınmaması, başarılarına çok da önem verilmemesi veya düşük gösterilmesi, örgüt içinde dışlanmaları, başka iş arkadaşlarının yanında aşağılanarak haklarında onur kırıcı konuşmaların yapılması, görevlerinin hep bilgi ve becerilerinin altında verilmesi, işinin sık sık kontrol edilerek sürekli hata aranması, kararları ve işle ilgili önerileri eleştirilerek reddedilmesi şeklinde psikolojik tacize maruz kaldıkları anlaşılmaktadır. Buna göre de araştırma neticesine dayanarak küçükbüyük ölçekli işletmelerde veya yöneticilerin olduğu kurumlarda (eğitim vs.) mobbinge karş1 bünyelerinde çeşitli tedbirler almaları önerilmektedir. Yapılan incelemenin tek bir kurumla sınırlı kalmasından dolayı genelleme yapılmasında bu incelemenin bulgu ve sonuçlarının yeterli olmayacağı göz önünde bulundurularak, bu araştırma konusu ile ilgili çalışacak 
araştırmacılar, farklı kurumlarda ve farklı uygulama alanlarında da bu ilişkiyi incelemeleri önerilmektedir.

\section{KAYNAKLAR}

ALTUNTAS, C. (2010). Mobbing kavrami ve örnekleri üzerine uygulamali bir çalişma. Journal of Yaşar University, 5(18), 2995-3015.

BENNIS, W. G., McGREGOR, C., \& SCHEIN, E. H. (1966). Leadership and motivation: essays of Douglas McGregor. Cambridge, Mass.: MIT Press.

CEVRIOGLU, E. (2007). Lider-Üye Etkileşimi ile Bireysel ve Örgütsel Sonuçlar Arasındaki İlişki: Ampirik Bir İnceleme, Yayınlanmamış Doktora Tezi, Afyon, Afyonkarahisar Kocatepe Üniversitesi Sosyal Bilimler Enstitüsü İşletme Anabilim Dalı.

CEKMECELIOGLU, H. G., \& DINCEL, G. (2013). Çalışanların iş tutum ve davranışlarının kurumsal itibar üzerindeki etkileri. Electronic Journal of Social Sciences, 12(47),125139.

CEKMECELIOGLU, H. G., \& GUNSEL, A. (2011). Rol stresi kaynaklarının iş tutumları açısından değerlendirilmesi: Kimya sektöründe bir uygulama. Organizasyon ve Yönetim Bilimleri Dergisi, 3(1), 33-43.

CILGA, I. (2009). Sosyal dışlanmanın dinamiği, bilimin, mesleğin dışlanması ve öngörüler. Journal of Society \& Social Work, 20(2), 7-26.

COBANOGLU, S. (2005). Mobbing ve başa çıkma yöntemleri. İstanbul: Timaş Yayıncılık.

DUFFY, M., \& SPERRY, L. (2007). Workplace mobbing: Individual and family health consequences. The Family Journal, 15(4), 398-404.

DUNDAR, G., \& ACAR, A. (2008). İşyerinde psikolojik yıldırmaya (mobbing) maruz kalma sıklığı ile demografik özellikler arasındaki ilişkinin incelenmesi. İstanbul Üniversitesi İşletme Fakültesi Dergisi, 37(2), 111-120.

ERDEM, O., \& DIKICI, A. M. (2009). Liderlik ve Kurum Kültürü Etkileşimi. Electronic Journal of Social Sciences, 8(29), 198-213.

FILIZ, Z., \& KOLUKISAOGLU, S. (2012). Doğrusal Olmayan Kanonik Korelasyon Analizi ve Bir Uygulama. Uluslararası Yönetim İktisat ve İşletme Dergisi, 8(16), 59-74.

GOKÇEK, H. (2006). Çalışanların Performans Değerlendirmesinde Tutumun Etkisi: Tutum Ölçekleri ile İlgili Bir Uygulama, Yüksek Lisans Tezi, Marmara Üniversitesi Sosyal Bilimler Enstitüsü.

GURBUZ, S., ERKUS, A., \& SIGRI, U. (2010). İş tatmini ve iş performansının yeni öncülü: temel benlik değerlendirmesi. Sosyal ve Beşerî Bilimler Dergisi, 2(1), 69-76.

IMMEGART, G. L. (1988). Leadership and leader behavior. Handbook of research on educational administration, 259-277.

JANSSEN, O., \& VAN YPEREN, N. W. (2004). Employees' goal orientations, the quality of leader-member exchange, and the outcomes of job performance and job satisfaction. Academy of management journal, 47(3), 368-384. 
KARAVARDAR, G. (2009). İş yaşamında psikolojik yıldırma ve psikolojik yıldırmaya direnç gösteren kişilik özellikleri ile ilişkisi. İstanbul Üniversitesi Sosyal Bilimler Enstitüsü Işletme Anabilim Dalı Insan Kaynakları Yönetimi Bilim Dalı (Yayınlanmamış Doktora Tezi), İstanbul.

KARCIOGLU, F., \& CELIK, U. (2012). Mobbing (yıldırma) ve örgütsel bağlılığa etkisi. Atatürk üniversitesi iktisadi ve idari bilimler dergisi, 26(1), 59-75.

KESKEN, J., \& AYYILDIZ, N. A. (2008). Liderlik yaklasimlarinda yeni perspektifler: pozitif ve otantik liderlik. Ege Academic Review, 8(2), 729-754.

KILIC, E. D., USTUN, A., \& ONEN, O. (2011). Öğrenen örgütlerde etkili liderlik: Burdur örneği. Educational Policy Analysis and Strategic Research, 6(1), 5-22.

LEWIS, D. (1996). Voices in The Social Work Environment And Health Outcomes. Europe Journal of Work Organizational Psyhol, 5, 65-81.

LEYMANN, H. (1990). Mobbing and psychological terror at workplaces. Violence and victims, 5(2), 119-126.

LEYMANN, H. (1996). The content and development of mobbing at work. European journal of work and organizational psychology, 5(2), 165-184.

LEYMANN, H., \& GUSTAFSSON, A. (1996). Mobbing at work and the development of post-traumatic stress disorders. European Journal of work and organizational psychology, 5(2), 251-275.

LIKERT, R. (1932). A technique for the measurement of attitudes. Archives of Psychology, $22140,55$.

McGREGOR, D. (1944). Conditions of effective leadership in the industrial organization. Journal of Consulting Psychology, 8(2), 55.

MEHMET, I., BEDUK, A., \& AYDOGAN, E. (2004). Örgütlerde takım çalışmasına yönelik etkin liderlik nitelikleri. Selçuk Üniversitesi Sosyal Bilimler Enstitüsü Dergisi, (11), 423-446.

ONEN, S. M., \& KANAYRAN, H. G. (2015). Liderlik ve motivasyon: kuramsal bir değerlendirme. Birey ve Toplum Sosyal Bilimler Dergisi, 5(2), 43-64.

SANTOS, J. R. A. (1999). Cronbach's alpha: A tool for assessing the reliability of scales. Journal of extension, 37(2), 1-5.

SARUHAN, S. C., \& YILDIZ, M. L. (2009). Çağdaş yönetim bilimi. Beta Basım Yayım Dağıtım.

SIMSEK, A. S. (2013). Mobbing Kaderimiz Midir?. Barış Araştırmaları ve Çatışma Çözümleri Dergisi, 1(2), 36-45.

TARLIG, Y.T. (2006). Performans Değerleme Süreci ile Performans Değerleme Sonuçlarının Kullanıldığı Alanlara Karşı Çalışan Tutumunu Belirlemeye Yönelik Bir Araştırma, Yüksek Lisans Tezi, Yıldız Teknik Üniversitesi Sosyal Bilimler Enstitüsü. 
TAS, A., \& ONDER, E. (2010). Yöneticilerin liderlik davranışlarının personel iş doyumuna etkisi. Elektronik Sosyal Bilimler Dergisi, 9(32), 17-30.

TINAZ, P. (2006). Mobbing: İşyerinde psikolojik taciz. Çalışma ve Toplum, 3, 1122.

UGURLUOGLU, O., \& CELIK, Y. (2009). Örgütlerde stratejik liderlik ve özellikleri. Hacettepe Sağlık İdaresi Dergisi, 12(2), 121-156.

VANDEKERCKHOVE, W., \& COMMERS, M. R. (2003). Downward workplace mobbing: a sign of the times?. Journal of business Ethics, 45(1-2), 41-50.

YAMAN, E. (2009). İşyerinde psikoşiddet-mobbing, Ankara: Nobel Yayınları.

ZEHIR, C., \& ERDOGAN, E. (2011). The association between organizational silence and ethical leadership through employee performance, Procedia Social and Behavioral Sciences, (24), 1389-1404.

ZUKAUSKAS, P., \& VVEINHARDT, J. (2009). Diagnosis of mobbing as discrimination in employee relations. Inžinerinè ekonomika, (4), 103-113. 